\title{
The Role of Cytomegalovirus in Angiogenesis
}

\author{
Patrizia Caposio*, Susan L. Orloff ${ }^{*}, \dagger, \ddagger$, and Daniel N. Streblow ${ }^{\star}, \S$ \\ "Department of Molecular Microbiology \& Immunology and The Vaccine \& Gene Therapy \\ Institute, Oregon Health \& Science University, Portland OR 97239
}

†Department of Surgery, Oregon Health \& Science University, Portland OR 97239

‡Portland VA Medical Center, Portland OR 97239

\section{Summary}

Human cytomegalovirus (HCMV) infection has been associated with the acceleration of vascular disease including atherosclerosis and transplant associated vasculopathy in solid organ transplants. HCMV promotes vascular disease at many of the different stages of the disease development. These include the initial injury phase, enhancing the response to injury and inflammation, as well as by increasing SMC hyperplasia and foamy macrophage cell formation. Angiogenesis is a critical process involved in the development of vascular diseases. Recently, HCMV has been shown to induce angiogenesis and this process is thought to contribute to HCMV-accelerated vascular disease and may also be important for HCMV-enhanced tumor formation. This review will highlight the role of HCMV in promoting angiogenesis.

\section{Angiogenesis}

New blood vessels are formed in response to normal physiological stimuli during fetal development, wound healing, and growth/development. However, neovascularization is also a consequence of numerous pathological conditions such as tumor growth, arthritis and is a prominent feature of vascular diseases like atherosclerosis and transplant associated vasculopathy and chronic allograft rejection. New blood vessels are formed in one of two processes deemed angiogenesis or vasculogenesis. While angiogenesis is the formation of new blood vessel sprouts from existing vessels, vasculogenesis is the term used to describe the formation of new fetal blood vessels in tissues lacking any pre-existing vessels, and this occurs through recruitment of endothelial cell (EC) progenitors. During vasculogenesis the newly formed blood vessels are subsequently extended and trimmed in a process that closely resembles angiogenesis. The formation of new vessels is a delicate process involving both pro- and anti-angiogenic factors that are integrated into the process occurs in discrete stages. Angiogenesis is initiated by the release of angiogenic factors including vascular endothelial growth factor (VEGF), as a reaction to tissue hypoxia or nutrient deprivation. This initial stage of angiogenesis is followed by the second stage, which removes pericytes surrounding the vessel resulting in breakdown of the basement membrane of the existing blood vessel wall. This process requires the activation of a number of different proteases including the matrix metalloproteinases (MMPs). The third stage of angiogenesis involves the breakdown

(C) 2010 Elsevier B.V. All rights reserved.

$\S_{\text {}}$ To whom correspondence may be addressed: Daniel N. Streblow Vaccine \& Gene Therapy Institute, Oregon Health \& Science University 505 SW 185 ${ }^{\text {th }}$ Beaverton, OR 97006 USA Phone: 503-418-2772 Fax: 503-418-2719 streblow@ohsu.edu.

Publisher's Disclaimer: This is a PDF file of an unedited manuscript that has been accepted for publication. As a service to our customers we are providing this early version of the manuscript. The manuscript will undergo copyediting, typesetting, and review of the resulting proof before it is published in its final citable form. Please note that during the production process errors may be discovered which could affect the content, and all legal disclaimers that apply to the journal pertain. 
of the basement membrane and extracellular matrix (ECM) with the release of latent growth factors that promote EC proliferation and migration towards the source of growth factor stimulation. The new vessel sprout forms by utilizing both specialized adhesion molecules as well as the breakdown of the extracellular matrix, as endothelial tip cells guide the developing tubule towards the source of angiogenic stimuli (VEGF). The EC sprout is then modified to become an unstable microvessel. Recently, it has been shown that M2macrophages act as bridging cells by localizing at the ends of two proximal tubules and promoting their fusion into one linked vessel (Fantin et al., 2010). During this last stage of angiogenesis mesenchymal cells are also recruited to the new vessel where they differentiate into mature pericytes that stabilize the neovessel. The resulting new vessels are capable of blood flow, aimed at relieving the hypoxic/nutrient-deprived state that was their stimulus for their formation. When the local development of neovessels is not sufficients to relieve hypoxic burden or when other factors such as CMV or tumor formation are driving this process, then additional vessels will be created by angiogenesis.

\section{Cytomegalovirus in Chronic Diseases That Involve Angiogenesis}

Human cytomegalovirus (HCMV) is a ubiquitous beta-herpesvirus that persists for the life of the human host following primary infection. Typically, HCMV infection of healthy, immunocompetent hosts results in subclinical disease. However, infection of immunocompromised individuals may cause serious life-threatening disease, which is still a significant problem in congenital disease and in bone marrow transplant recipients. HCMV has been associated with long-term diseases including the vascular diseases atherosclerosis, restenosis following angioplasty, and transplant vascular sclerosis (TVS) associated with chronic allograft rejection of solid organ grafts (Almond et al., 1993; Melnick et al., 1998; Speir et al., 1994). Recently, HCMV has been detected in human glioblastoma (GBM), and it has been suggested that HCMV exacerbates the progression of this disease (Cobbs et al., 2002; Scheurer et al., 2008). A common feature of both vascular disease and GBM formation is angiogenesis and CMV may enhance these diseases by accentuating pathologic angiogenesis.

Determining the mechanisms of HCMV's involvement in the acceleration of vascular disease and GBM formation has been difficult because the etiologies of these chronic diseases are multifactorial. In addition, HCMV is ubiquitous throughout the human population making negative controls uncommon. Furthermore, HCMV infects many different cell types involved in angiogenesis including endothelial cells (EC), smooth muscle cells (SMC), macrophages and fibroblasts, making it difficult to determine a temporal relationship between virus infection and disease process. Animal and human studies have shown that CMV is involved in accelerating both acute and chronic graft failure in all types of solid organ transplants by promoting the vascular disease associated with rejection. HCMV DNA has been detected in the vasculature of transplanted organs from CMV positive donors demonstrating that the allograft may be an important source of virus (Wu et al., 1992). HCMV infection in cardiac allograft recipients, doubles the 5-year rate of graft failure due to accelerated TVS and chronic rejection (Grattan et al., 1989). Additional proof of HCMV's role in graft vasculopathy comes from the finding of a higher incidence of viral DNA detected in the explant vascular intima of patients with cardiac allograft TVS than in those explants without vasculopathy (Wu et al., 1992). Importantly, treatment of heart transplant recipients with ganciclovir, a potent inhibitor of viral replication and HCMV disease, delayed the time to the development of allograft rejection, demonstrating that viral replication is important for acceleration of disease (Merigan et al., 1992; Valantine et al., 1999). Furthermore, kidney transplant allograft survival was decreased in asymptomatic HCMV-infected recipients during the first 100 days post transplantation compared to patients with no HCMV infection suggesting that the presence of HCMV alone, whether 
asymptomatic or with overt infection, has a negative impact on graft survival (Hodson et al., 2005). Similarly, using rat heart, kidney, lung and small bowel transplantation models of chronic rejection, it has been shown that acute infection with ratCMV (RCMV) dramatically decreases the mean time to graft failure, and also increases the degree of vasculopathy in the allograft vessels (Orloff et al., 2002; Orloff et al., 2000; Streblow et al., 2003). Antiviral therapy can prevent or at least reduce the acceleration of rejection in the rat transplant models demonstrating that, similar to the human scenario, active CMV replication is very important for these disease processes (Tikkanen et al., 2001; Zeng et al., 2005).

Studies on human atherectomy specimens, with and without angioplasty, have shown that HCMV sero-positivity correlated with the presence of inactivated tumor suppressor gene $\mathrm{p} 53$, which has been proposed to induce the excessive accumulation of SMC in the developing neointima contributing to restenosis (Speir et al., 1995; Speir et al., 1994). Rat models of carotid artery balloon angioplasty have been used to study the effects of CMV on acceleration of restenosis and it has been found that CMV-infected animals have a $40 \%$ greater neointimal formation when compared to controls (Zhou et al., 1995). While the strongest association of CMV in vascular disease is with the development of restenosis and TVS, an association exists with atherosclerosis as well. CMV seropositive individuals are 2-3 fold more likely to develop coronary artery disease compared to HCMV seronegative patients (Muhlestein et al., 2000). In support of this association, HCMV antigens and nucleic acids have been detected in early lesions of diseased vessels (Hendrix et al., 1989; Hendrix et al., 1990; Melnick et al., 1983; Speir et al., 1994; Zhou et al., 1996). For example, studies have detected HCMV DNA in the vascular tissues from $76 \%$ of patients with ischemic heart disease (Horvath et al., 2000) and up to 53\% of carotid artery atherosclerotic lesions (Qavi et al., 2000). In addition, in thoracic aorta sections, HCMV was frequently detected in fatty streaks and normal-appearing areas of diseased vessels near intercostal artery openings (Melnick et al., 1983; Pampou et al., 2000). Animal models, especially genetically altered mice, have provided definitive evidence that CMV plays an important role in atherosclerosis. A few groups have shown that murine-CMV (MCMV) infection of apoE-/mice increases the severity of atherosclerosis (Hsich et al., 2001; Streblow et al., 2001; Vliegen et al., 2004a; Vliegen et al., 2004b; Vliegen et al., 2002).

Recently, HCMV infection has been associated with several human malignancies including prostate and colon cancers as well as glioblastoma multiforme (GBM) (Soderberg-Naucler, 2006). GBM is the most common type of highly malignant brain cancer and currently has no effective treatment (Louis et al., 2007). HCMV DNA has been reported to be present in over 90\% of human malignant gliomas (Cobbs et al., 2002; Mitchell et al., 2008b), suggesting a role for HCMV in glioma oncogenesis. A recent report has strengthened the connection between HCMV and GBM by demonstrating that vaccination against the HCMV tegument protein pp65 can improve survival in GBM patients (Mitchell et al., 2008a). While the molecular mechanisms of HCMV's participation in glioblastoma development remain unclear, a role of angiogenesis in tumor formation is certain. HCMV infection may enhance GBM formation by increasing angiogenesis in the tumor, which would result in increased tumor vascularity and survival.

\section{Role of Endothelial Cells in Normal Physiology and During CMV Infection}

Endothelial cells (ECs) are a key cellular component of several physiological processes, such as angiogenesis, regulation of coagulation, tissue homeostasis, inflammation, vessel growth, and are an important site of CMV persistence in the host. ECs differentiate from angioblasts in the embryo (Mikkola and Orkin, 2002) and from endothelial progenitor cell (EPCs), mesoangioblasts, multipotent adults progenitor cells, or side-population cells in the adult bone marrow (Luttun et al., 2002; Reyes et al., 2002). ECs form the inner lining of 
blood and lymphatic vessels throughout the body and share a number of phenotypic characteristics. However, additional requirements of EC to perform highly specialized, tissue-specific functions result in a wide diversification of EC phenotypes according to anatomic location and tissue source. The high level of EC diversity was initially suggested by morphological differences between individual cell types (Conway and Carmeliet, 2004). Analysis of antigen expression by ECs from different vascular sources broaden our understanding of the repertoire of ECs throughout the systemic vasculature and revealed that ECs are extremely heterogenous and express unique cell surface antigens that together comprise an EC "vascular address" system (Ruoslahti and Rajotte, 2000).

Analysis of tissues from healthy individuals in the absence of acute disease identifies a number of cells types that may serve as sites of CMV persistent or latent infection in the normal individuals. Early studies identified HCMV DNA, mRNA, and antigen within the vessel walls of the major arteries throughout the body (Gyorkey et al., 1984; Hendrix et al., 1989; Hendrix et al., 1990; Melnick et al., 1983; Yamashiroya et al., 1988). To function as a site of HCMV persistence, virus infection would be expected to cause minimal cytopathology. Consistent with this requirement, HCMV infection in these healthy individuals was frequently observed in healthy, histologically normal arteries. More recently, ECs were definitively shown to be one of the cell types infected by HCMV within the arterial wall on the basis of viral DNA and antigen positivity in cells stained for an EC marker (Pampou et al., 2000). However, only a subset of HCMV DNA positive ECs were observed to contain detectable levels of viral antigen, identifying ECs as a potential site of latency as well as a reservoir for persistent viral replication in healthy individuals. The effect of EC diversity in CMV replication and pathogenesis remains largely unaddressed. For example, DNA array analyses show that micro- and macrovascular EC differ considerably in expression levels of various molecules involved in CMV entry, such as integrins and epidermal growth factor receptor (Chi et al., 2003; Kallmann et al., 2002). Indeed, levels of HCMV infection in macrovascular umbilical vein ECs (HUVECs) compared to intestinal microvasculare ECs have been shown to be significantly decreased (Sindre et al., 2000), and virus in HUVECs compared to other macrovasculature (aortic) and microvasculature (uterine) is similarly reduced by 10 - to 100 -fold (Maidji et al., 2002). ECs also differ in other characteristics associated with HCMV infection. For example, a comparison of HCMV infection in brain microvasculature (BMVECs) and aortic macrovascular ECs (AECs) show that, although both EC types express viral proteins and support HCMV replication, virus failed to accumulate intracellularly in AECs, resulting in reduced levels of cell-associated virus compared to supernatant virus. This difference in the distribution of virus corresponds to a lytic infection in BMVECs, but not in AECs, and suggests that efficient release of mature intracellular virions may prolong cell survival. Furthermore, the ability of the virus to infect the vascular endothelium is critical in the pathogenesis of all HCMV diseases (Bissinger et al., 2002; Jarvis and Nelson, 2002; Kahl et al., 2000). Importantly, HCMV has the ability to increase the adhesion properties of endothelium (Caposio et al., 2007), endothelium permeability (Bentz et al., 2006) and to create a pro-inflammatory environment (Caposio et al., 2007; Dengler et al., 2000; Streblow et al., 2008a) that can promote the first step in the angiogenesis process.

\section{How Does CMV Promote Angiogenesis?}

CMV typically infects all of the cell types involved in angiogenesis and vascular disease including ECs, smooth muscle cells, pericytes, fibroblasts, and macrophages and promotes angiogenesis by both direct and indirect mechanisms. In addition, infection at sites proximal to the vessel may promote angiogenesis by releasing angiogeneic factors or by increasing local inflammation (angiogenic factors induced by CMV infection are listed in Table 1). To this end, CMV infection of fibroblasts and EC promotes the synthesis and release of a 
number of angiogeneic factors that stimulate many of the stages of angiogenesis (Dumortier et al., 2008). Similarly, the production of angiogenic factors occurs during solid organ graft rejection and this process is exacerbated during CMV infection (Streblow et al., 2008a; Streblow et al., 2008b). For the purposes of this review, we characterize angiogenesis in four stages, as shown in Figure 1; we will focus on elucidating HCMV's role during these stages of pathological angiogenesis.

\subsection{Stage 1. Promotion of Angiogenesis: Release of Angiogenic Factors and EC Activation}

Angiogenesis is rapidly initiated in response to hypoxia, inflammation, and injury. Vascular relaxation, for example, mediated by nitric oxide (NO) is a prerequisite for EC to enter the angiogenic cascade (Marinos et al., 2001). Although low concentrations of NO induce an angiogenic response, high concentrations are inhibitory (Isenberg et al., 2005). Indeed, reduced endothelial nitric oxide synthase (eNOS) expression and activity is a common feature in various cardiovascular diseases including that seen in HCMV-seropositive individuals (Grahame-Clarke et al., 2003). Shen et al. have shown that HCMV infection prevents eNOS activation by inhibiting Akt pathway in EC (Shen et al., 2006). HCMV infection of ECs induces the expression of the adhesion molecules ICAM-1 and VCAM-1 (Table 1), which enhance transendothelial cell migration of inflammatory cells including monocytes (Steinhoff et al., 1995). These tissue resident macrophages are known to promote angiogenesis by secreting VEGF. In addition, Maussang et al. have shown that the HCMVencoded chemokine receptor US28 induces cyclooxygenase-2 (COX-2) expression via activation of nuclear factor-kB, driving the production of VEGF, which promotes angiogenesis (Maussang et al., 2009). We have shown that US28 promotes the migration of macrophages in response to Fractalkine (Vomaske et al., 2009), which may enhance angiogenesis by steering the $\mathrm{CMV}$-infected cells to areas of inflammation.

In response to an angiogenic stimulus, EC's become activated and they attract and bind leukocytes and platelets that subsequently release a multitude of pro-and anti-agiogenic factors (Bouis et al., 2006). We have shown that HCMV infection alters the types and quantities of bioactive proteins released from infected cells. We have designated these released proteins the 'HCMV secretome' (Dumortier et al., 2008). The HCMV secretome from infected fibroblasts and ECs, but not mock-infected cells, promotes angiogenesis in a standard matrigel assay. The RCMV secretome had paralleled activity in promoting angiogenesis. However, the HSV-1 secretome, derived from fibroblasts, failed to induce angiogenesis (Dumortier et al., 2008; Streblow et al., 2008b). These findings indicate that CMV infection uniquely promote the release of soluble factors that drive angiogenesis as this effect is not a common feature of all herpesvirus infections. Mass spectrometry (MS) analysis of the HCMV-infected and mock-infected secretomes identified more than 1,200 proteins, more than 1,000 of which were specific or highly enriched in the HCMV secretome. Pathway analysis indicates that a large number of angiogenic proteins were present in the HCMV secretome, i.e., proteins involved in transforming growth factor $\beta$ (TGF- $\beta$ ) and other growth factor signaling pathways, cytokines, and chemokines, as well as factors involved in ECM remodeling. A human cytokine antibody array was used to validate the MS studies and to provide relative quantification of the signature proteins present in the secretome. The most highly abundant cellular factors identified in the HCMV secretome that are known to contribute to angiogenesis include the cytokines/chemokines (IL-6, osteoprotegerin, GRO, CCL3, CCL5, CCL7, CCL20, CXCL-5, and CXCL-16), receptors (TNF-RI and II and ICAM-1), growth factors (TGF- $\beta 1$, HGF and GM-CSF), ECM modifiers (MMP-1, TIMP-1, TIMP-2, TIMP-4), and the angiogenic RNase angiogenin. HCMV also encodes CC and CXC chemokines homologues (Beisser et al., 2008), known to possess proliferative, chemotactic and angiogenic properties. Importantly, in support of these findings, a rat heart transplantation model used to study the role of CMV in the 
development of transplant vascular sclerosis (TVS), a pathological process associated with chronic allograft rejection, characterized by chronic perivascular inflammation, EC dysfunction, and SMC migration, RCMV infection induces the upregulation of approximately 134 genes that are known mediators of angiogenesis and wound healing. These mediators include angiopoietin, cathepsins, chemokines, the CNN family, endothelin, $\mathrm{ECM} / \mathrm{BM}$ components (laminin, fibronectin, osteopontin, tenascin); the EGF family; hematopoietic growth factors, the insulin growth factor binding protein (IGFBP) family, MMPs, platelet derived growth factor (PDGF); TGF- $\beta$; tumor necrosis factor receptor (TNFR) superfamily; urokinase-type plasminogenon activator and receptor (uPA/uPAR), and vascular endothelial growth factor (VEGF) (Streblow et al., 2003; Streblow et al., 2008b). Thus, on aggregate, CMV infection has been shown to directly and indirectly influence the initiation of angiogenesis on multiple levels including the induction of the release of the angiogenic factors VEGF and IL-6.

\subsection{Stage 2. Degradation of the Basal Lamina}

After proper EC activation, endothelial penetration into new areas of the body, and hence angiogenesis, is achieved by degradation of the basal membrane (BM) by matrix metalloproteinases (MMPs). These extracellular endopeptidases are secreted as zymogens that become activated in the ECM compartment and subsequently selectively degrade components of the ECM (Stetler-Stevenson, 1999). They are produced by a variety of cells, including epithelial cells, fibroblasts, inflammatory cells, and ECs. MMP activity and, consequently, angiogenesis is counteracted by the family of tissue inhibitors of metalloproteinase (TIMPs) (Gomez et al., 1997; Valente et al., 1998). The HCMV secretome from infected fibroblasts and EC contain a number of proteins involved in ECM remodeling including a number of matrix metalloproteinases (MMP-1, -2, -3, -10, -12, and -19), cathepsins (B, D, F, K, L, and S), and tissue inhibitors of matrix metalloproteinases (TIMP-1, -2, and -3) (Dumortier et al., 2008). Many of these same factors are upregulated during RCMV-accelerated TVS formation in rat cardiac allografts (Streblow et al., 2008a; Streblow et al., 2008b). In addition, RCMV infection results in a cell-type specific increase in gene expression of MMPs. For example, MMP-2 and MMP-14 were up-regulated only in fibroblasts whereas MMP-9 and MMP-12 were upregulated in EC, SMC and fibroblasts. Moreover, increased MMP-2 activity is observed in HCMV-infected cells in conjunction with a reduction in extracellular matrix gene expression (Reinhardt et al., 2006;

Schaarschmidt et al., 1999). Thus, CMV infection can promote degradation of the basement membrane lining the outer vessel wall through the release of a number of proteases including the MMPs.

\subsection{Stage 3. Cellular Migration}

Cellular migration is an extremely important part of angiogenesis. First, EC must migrate out of the vessel wall to form the initial sprout. Then they must migrate towards the sites of growth factor stimulation in order to form the tubule and eventual vessel. In addition, during the last stage of angiogenesis, pericytes (SMCs or fibroblasts) migrate to the newly formed tubules in order to stabilize the vessel during the final stage of angiogenesis. However, during pathologic angiogenesis migration of other cells is key to enhancing vascular disease, which concomitantly induces angiogenesis. These migratory cell types that participate in this process include inflammatory cells (macrophages, T cells, B cells and NK cells), platelets, and SMC. HCMV plays a multifaceted role in cellular migration by direct and indirect mechanisms.

HCMV indirectly promotes migration through the infection process itself. Infected monocyte/macrophages are known to disseminate HCMV throughout the body including the vasculature. HCMV binding and entry of monocytes has been shown to signal through the 
epidermal growth factor receptor (EGFR) and activate N-WASP which promotes monocyte motility and diapedesis (Chan et al., 2009). The infected monocytes enter the vasculature and mature there, and during this process, the initiation of the viral infection program occurs, which in turn stimulates virus replication. The resident infected macrophages disseminate the virus to other cells of the vasculature including SMCs. We have observed that the HCMV-encoded chemokine receptor US28 can stimulate the migration of vascular SMC and macrophages in a ligand-dependent manner. However, US28-mediated migration does not occur through the same pathways in both cell types (Vomaske et al., 2009). SMC migration is mediated by binding to CC-chemokines and is blocked by the CX3Cchemokine Fractalkine (Streblow et al., 1999; Vomaske et al., 2009). In contrast, macrophage migration induced by US28 occurs after ligation with Fractalkine but not CCchemokines. This suggests a dual role for US28 in migration that is both cell type and ligand specific. In addition to its role in directly promoting cellular migration, US28 signaling has recently been reported to produce a transformed phenotype in transfected NIH-3T3 cells, which is characterized by an increased expression of the pro-angiogenic marker VEGF (Maussang et al., 2006). As mentioned above VEGF is a key mediator of angiogenesis and mediates EC migration; thus US28 appears to have multiple roles in promoting angiogenesis.

Chemokines play a major role in the development of vascular disease and angiogenesis. HCMV infection has been shown to up-regulate the expression of a number of cellular chemokines including MIP1- $\alpha \& \beta$, RANTES and IL-8 (Cheeran et al., 2001; RandolphHabecker et al., 2002; Streblow et al., 1999). The overall effect of the CMV-induced chemokine up-regulation is an increase in cellular migration of both infected and uninfected cells such as peripheral blood cells. The CMV family also encodes chemokine homologues. HCMV encodes one CC-chemokine (UL128) and two CXC-chemokines (UL146 and UL147) (Cha et al., 1996). UL146 or vCXCL1 was shown to induce the migration of neutrophils by binding to the cellular CXCR2 receptor (Penfold et al., 1999; Sparer et al., 2004). The most well characterized CMV encoded CC-chemokine is the MCMV m129/131 chemokine or MCK-2, which recruits immature myelomoncytic leukocytes from the bone marrow to sites of MCMV infection and promotes viral dissemination (Noda et al., 2006).

\subsection{Stage 4. New Vessel Formation and Stabilization}

During the last stage of angiogenesis two newly formed tubules that are closely positioned will become connected and then stabilized through the addition of pericytes to the outer wall. Endothelial cell interaction with ECM and mesenchymal cells is a prerequisite to form stable vasculature. Therefore, after the formation of endothelial tubule structures, surrounding vessel layers composed of mural cells (pericytes in small vessels and smooth muscle cells in large vessels), need to be recruited. ECs may accomplish this via the synthesis and secretion of PDGF, a mitogen and chemoattractant for a variety of mesenchymal cells, and TGF- $\beta$, which may induce changes in myofibroblasts and pericytes contributing to the formation of a quiescent vessel, ECM production, and maintenance of growth control. Many components of the HCMV secretome are involved not only in the formation but also in vessel stabilization. PDGF and TGF- $\beta$ are secreted from both HCMVinfected fibroblasts and ECs (Dumortier et al., 2008) and are also present in heart allografts from RCMV-infected rats (Streblow et al., 2008a; Streblow et al., 2008b). Previously, a few groups have shown that HCMV infection of EC increases the expression of FGF and PDGFBB (Inkinen et al., 2003; Lemstrom and Koskinen, 1997; Reinhardt et al., 2005). FGF-1 is also implicated in EC differentiation leading to vascular tube formation. Besides inducing EC proliferation and migration, FGF-1 receptor signaling results in endothelial tube formation in collagen (Kanda et al., 1996). Indeed, in the RCMV-accelerated TVS rat heart transplant model, RCMV infection upregulates the FGF-1 receptor, which lends further 
support to the role of cytomegalovirus in every step of angiogenesis. In a recent publication Fantin and co-workers (Fantin et al., 2010) have shown that macrophages play an important role during the anastomosis process of new vessels. The tissue macrophages serve as both "bridge cells" and guidance posts to properly position the budding vessel branches. Macrophages can regulate the growth and remodeling of blood and lymph vessels through different mechanisms. Type M1 macrophages inhibit angiogenesis by initiating a cell-death program in ECs. Type M2 macrophages promote angiogenesis by releasing pro-angiogenic factors such as VEGF and VEGF-C, and thereby induce endothelial tip cell formation. The macrophages that Fantin and colleagues describe are polarized towards the M2 type.

Monocytes are also a primary in vivo target for HCMV (Rice et al., 1984), and act as a site of viral latency and persistence (Sinzger et al., 1996). These cells are also the primary infiltrating cell types found in HCMV-infected organs, and their aberrant function following HCMV infection is implicated in atherosclerosis (Degre et al., 2001; Pulliam, 1991). HCMV infection selectively modulates M1- and M2-associated factors, resulting in an activated monocyte phenotype, which spans the M1/M2 polarization spectrum in an effort to balance viral spread with immune evasion (Chan et al., 2008). The mechanisms involved in macrophage recognition of and assistance in fusing the endothelial tip cells remains a mystery. However, one explanation could be that macrophages express Notch receptor and tip cells express Dll4-a ligand that activates Notch (Hellstrom et al., 2007a; Hellstrom et al., 2007b). Interestingly, in the transcriptome analysis of HCMV-activated monocyte/ macrophages, proposed by Chan and colleagues, Notch 2 receptor is up-regulated at 4 hours post infection (Chan et al., 2008). Thus HCMV may affect the stability of the neovessel through the release of cytokines and growth factors. Indeed, we have demonstrated that the HCMV secretome from both fibroblasts and ECs can stabilize tubules for a substantially longer period of time compared to cells treated with a mock secretome or those cultures treated with $10 \%$ serum as a positive control, which highlights the significant effect that HCMV plays in this process.

\section{Conclusions}

HCMV has been implicated in the development of chronic diseases that involve angiogenesis. In this review we highlight the mechanisms by which HCMV can promote angiogenesis and stabilize neovessel formation leading to pathologic angiogenesis. HCMV can promote or enhance all of the stages of angiogenesis (Figure 1). For example, HCMV infected cells directly induce angiogenesis by secreting VEGF and/or other angiogenic factors (Table 1). HCMV can also activate EC and induce their proliferation; and factors shed from infected cells (secretome) have the direct effect of promoting tubule formation and stabilization. HCMV-encoded chemokine receptors can mobilize infected cells to sites of inflammation, including those undergoing angiogenesis, or attract other cells to these sites via the virus-encoded chemokine ligands. HCMV infection may also have detrimental pathologic consequences on this process by either dysregulating the normal angiogenesis process or by promoting inflammation, which would negatively impact the finishing stages of angiogenesis.

\section{Acknowledgments}

This work was supported by research grants from the National Institutes of Health to D.N. Streblow (HL083194), S.L. Orloff (HL 085451) and J.A. Nelson (HL 088603).

\section{References}

Almond PS, Matas A, Gillingham K, Dunn DL, Payne WD, Gores P, Gruessner R, Najarian JS. Risk factors for chronic rejection in renal allograft recipients. Transplant. 1993; 55(4):752-6. discussion $756-7$. 
Beisser PS, Lavreysen H, Bruggeman CA, Vink C. Chemokines and chemokine receptors encoded by cytomegaloviruses. Curr Top Microbiol Immunol. 2008; 325:221-42. [PubMed: 18637509]

Bentz GL, Jarquin-Pardo M, Chan G, Smith MS, Sinzger C, Yurochko AD. Human cytomegalovirus (HCMV) infection of endothelial cells promotes naive monocyte extravasation and transfer of productive virus to enhance hematogenous dissemination of HCMV. J Virol. 2006; 80(23):1153955. [PubMed: 16987970]

Bissinger AL, Sinzger C, Kaiserling E, Jahn G. Human cytomegalovirus as a direct pathogen: correlation of multiorgan involvement and cell distribution with clinical and pathological findings in a case of congenital inclusion disease. J Med Virol. 2002; 67(2):200-6. [PubMed: 11992580]

Bouis D, Kusumanto Y, Meijer C, Mulder NH, Hospers GA. A review on pro- and anti-angiogenic factors as targets of clinical intervention. Pharmacol Res. 2006; 53(2):89-103. [PubMed: 16321545]

Caposio P, Musso T, Luganini A, Inoue H, Gariglio M, Landolfo S, Gribaudo G. Targeting the NFkappaB pathway through pharmacological inhibition of IKK2 prevents human cytomegalovirus replication and virus-induced inflammatory response in infected endothelial cells. Antiviral Res. 2007; 73(3):175-84. [PubMed: 17070604]

Cha TA, Tom E, Kemble GW, Duke GM, Mocarski ES, Spaete RR. Human cytomegalovirus clinical isolates carry at least 19 genes not found in laboratory strains. J Virol. 1996; 70(1):78-83. [PubMed: 8523595]

Chan G, Bivins-Smith ER, Smith MS, Yurochko AD. Transcriptome analysis of NF-kappaB- and phosphatidylinositol 3-kinase-regulated genes in human cytomegalovirus-infected monocytes. J Virol. 2008; 82(2):1040-6. [PubMed: 18003728]

Chan G, Nogalski MT, Yurochko AD. Activation of EGFR on monocytes is required for human cytomegalovirus entry and mediates cellular motility. Proc Natl Acad Sci U S A. 2009; 106(52): 22369-74. [PubMed: 20018733]

Cheeran MC, Hu S, Yager SL, Gekker G, Peterson PK, Lokensgard JR. Cytomegalovirus induces cytokine and chemokine production differentially in microglia and astrocytes: antiviral implications. Journal of Neurovirology. 2001; 7(2):135-47. [PubMed: 11517386]

Chi JT, Chang HY, Haraldsen G, Jahnsen FL, Troyanskaya OG, Chang DS, Wang Z, Rockson SG, van de Rijn M, Botstein D, Brown PO. Endothelial cell diversity revealed by global expression profiling. Proc Natl Acad Sci U S A. 2003; 100(19):10623-8. [PubMed: 12963823]

Cobbs CS, Harkins L, Samanta M, Gillespie GY, Bharara S, King PH, Nabors LB, Cobbs CG, Britt WJ. Human cytomegalovirus infection and expression in human malignant glioma. Cancer Res. 2002; 62(12):3347-50. [PubMed: 12067971]

Conway EM, Carmeliet P. The diversity of endothelial cells: a challenge for therapeutic angiogenesis. Genome Biol. 2004; 5(2):207. [PubMed: 14759250]

Degre M, Kristiansen KI, Rollag H, Holter E, Nordal KP. Detection of human cytomegalovirus (HCMV) pp67-mRNA and pp65 antigenemia in relation to development of clinical HCMV disease in renal transplant recipients. Clin Microbiol Infect. 2001; 7(5):254-60. [PubMed: 11422252]

Dengler TJ, Raftery MJ, Werle M, Zimmermann R, Schonrich G. Cytomegalovirus infection of vascular cells induces expression of pro- inflammatory adhesion molecules by paracrine action of secreted interleukin-1beta. Transplantation. 2000; 69(6):1160-8. [PubMed: 10762222]

Dumortier J, Streblow DN, Moses AV, Jacobs JM, Kreklywich CN, Camp D, Smith RD, Orloff SL, Nelson JA. Human cytomegalovirus secretome contains factors that induce angiogenesis and wound healing. J Virol. 2008; 82(13):6524-35. [PubMed: 18448536]

Fantin A, Vieira JM, Gestri G, Denti L, Schwarz Q, Prykhozhij S, Peri F, Wilson SW, Ruhrberg C. Tissue macrophages act as cellular chaperones for vascular anastomosis downstream of VEGFmediated endothelial tip cell induction. Blood. 2010

Gomez DE, Alonso DF, Yoshiji H, Thorgeirsson UP. Tissue inhibitors of metalloproteinases: structure, regulation and biological functions. Eur J Cell Biol. 1997; 74(2):111-22. [PubMed: 9352216]

Grahame-Clarke C, Chan NN, Andrew D, Ridgway GL, Betteridge DJ, Emery V, Colhoun HM, Vallance P. Human cytomegalovirus seropositivity is associated with impaired vascular function. Circulation. 2003; 108(6):678-83. [PubMed: 12900349] 
Grattan MT, Moreno-Cabral CE, Starnes VA, Oyer PE, Stinson EB, Shumway NE. Cytomegalovirus infection is associated with cardiac allograft rejection and atherosclerosis. JAMA. 1989; 261(24): 3561-6. [PubMed: 2542633]

Gyorkey F, Melnick JL, Guinn GA, Gyorkey P, DeBakey ME. Herpesviridae in the endothelial and smooth muscle cells of the proximal aorta in arteriosclerotic patients. Exp. Mol. Pathol. 1984; 40:328-339. [PubMed: 6723937]

Hellstrom M, Phng LK, Gerhardt H. VEGF and Notch signaling: the yin and yang of angiogenic sprouting. Cell Adh Migr. 2007a; 1(3):133-6. [PubMed: 19262131]

Hellstrom M, Phng LK, Hofmann JJ, Wallgard E, Coultas L, Lindblom P, Alva J, Nilsson AK, Karlsson L, Gaiano N, Yoon K, Rossant J, Iruela-Arispe ML, Kalen M, Gerhardt H, Betsholtz C. Dl14 signalling through Notch1 regulates formation of tip cells during angiogenesis. Nature. 2007b; 445(7129):776-80. [PubMed: 17259973]

Hendrix M, Dormans PHJ, Kitseelar P, Bosman F, Bruggeman CA. The presence of CMV nucleic acids arterial walls of atherosclerotic and non-atherosclerotic patients. Am. J. Path. 1989; 134:1151-7. [PubMed: 2541613]

Hendrix MG, Salimans MM, van Boven CP, Bruggeman CA. High prevalence of latently present cytomegalovirus in arterial walls of patients suffering from grade III atherosclerosis. Am J Pathol. 1990; 136(1):23-8. [PubMed: 2153348]

Hodson EM, Jones CA, Webster AC, Strippoli GF, Barclay PG, Kable K, Vimalachandra D, Craig JC. Antiviral medications to prevent cytomegalovirus disease and early death in recipients of solidorgan transplants: a systematic review of randomised controlled trials. Lancet. 2005; 365(9477): 2105-15. [PubMed: 15964447]

Horvath R, Cerny J, Benedik J, Hokl J, Jelinkova I. The possible role of human cytomegalovirus (HCMV) in the origin of atherosclerosis. J Clin Virol. 2000; 16(1):17-24. [PubMed: 10680737]

Hsich E, Zhou YF, Paigen B, Johnson TM, Burnett MS, Epstein SE. Cytomegalovirus infection increases development of atherosclerosis in Apolipoprotein-E knockout mice. Atherosclerosis. 2001; 156(1):23-8. [PubMed: 11368993]

Inkinen K, Holma K, Soots A, Krogerus L, Loginov R, Bruggeman C, Ahonen J, Lautenschlager I. Expression of TGF-beta and PDGF-AA antigens and corresponding mRNAs in cytomegalovirusinfected rat kidney allografts. Transplant Proc. 2003; 35(2):804-5. [PubMed: 12644146]

Isenberg JS, Ridnour LA, Perruccio EM, Espey MG, Wink DA, Roberts DD. Thrombospondin-1 inhibits endothelial cell responses to nitric oxide in a cGMP-dependent manner. Proc Natl Acad Sci U S A. 2005; 102(37):13141-6. [PubMed: 16150726]

Jarvis MA, Nelson JA. Human cytomegalovirus persistence and latency in endothelial cells and macrophages. Curr Opin Microbiol. 2002; 5(4):403-7. [PubMed: 12160860]

Kahl M, Siegel-Axel D, Stenglein S, Jahn G, Sinzger C. Efficient lytic infection of human arterial endothelial cells by human cytomegalovirus strains. J Virol. 2000; 74(16):7628-35. [PubMed: 10906217]

Kallmann BA, Wagner S, Hummel V, Buttmann M, Bayas A, Tonn JC, Rieckmann P. Characteristic gene expression profile of primary human cerebral endothelial cells. Faseb J. 2002; 16(6):589-91. [PubMed: 11919163]

Kanda S, Landgren E, Ljungstrom M, Claesson-Welsh L. Fibroblast growth factor receptor 1-induced differentiation of endothelial cell line established from tsA58 large T transgenic mice. Cell Growth Differ. 1996; 7(3):383-95. [PubMed: 8838868]

Lemstrom KB, Koskinen PK. Expression and localization of platelet-derived growth factor ligand and receptor protein during acute and chronic rejection of rat cardiac allografts. Circulation. 1997; 96(4):1240-9. [PubMed: 9286955]

Louis DN, Ohgaki H, Wiestler OD, Cavenee WK, Burger PC, Jouvet A, Scheithauer BW, Kleihues P. The 2007 WHO classification of tumours of the central nervous system. Acta Neuropathol. 2007; 114(2):97-109. [PubMed: 17618441]

Luttun A, Carmeliet G, Carmeliet P. Vascular progenitors: from biology to treatment. Trends Cardiovasc Med. 2002; 12(2):88-96. [PubMed: 11852257] 
Maidji E, Percivalle E, Gerna G, Fisher S, Pereira L. Transmission of human cytomegalovirus from infected uterine microvascular endothelial cells to differentiating/invasive placental cytotrophoblasts. Virology. 2002; 304(1):53-69. [PubMed: 12490403]

Marinos RS, Zhang W, Wu G, Kelly KA, Meininger CJ. Tetrahydrobiopterin levels regulate endothelial cell proliferation. Am J Physiol Heart Circ Physiol. 2001; 281(2):H482-9. [PubMed: 11454549]

Maussang D, Langemeijer E, Fitzsimons CP, Stigter-van Walsum M, Dijkman R, Borg MK, Slinger E, Schreiber A, Michel D, Tensen CP, van Dongen GA, Leurs R, Smit MJ. The human cytomegalovirus-encoded chemokine receptor US28 promotes angiogenesis and tumor formation via cyclooxygenase-2. Cancer Res. 2009; 69(7):2861-9. [PubMed: 19318580]

Maussang D, Verzijl D, van Walsum M, Leurs R, Holl J, Pleskoff O, Michel D, van Dongen GA, Smit MJ. Human cytomegalovirus-encoded chemokine receptor US28 promotes tumorigenesis. Proc Natl Acad Sci U S A. 2006; 103(35):13068-73. [PubMed: 16924106]

Melnick JL, Adam E, DeBakey ME. The link between CMV and atherosclerosis. Infect. Med. 1998; 15:479-86.

Melnick JL, Petrie BL, Dreesman GR, Burek J, McCollum CH, DeBakey ME. Cytomegalovirus antigen within human arterial smooth msucle cells. Lancet. 1983; 322:644-7. [PubMed: 6136795]

Merigan TC, Renlund DG, Keay S. A controlled trial of ganciclovir to prevent cytomegalovirus disease after heart transplantation. N Engl J Med. 1992; 326:1182-6. al., e. [PubMed: 1313549]

Mikkola HK, Orkin SH. The search for the hemangioblast. J Hematother Stem Cell Res. 2002; 11(1): 9-17. [PubMed: 11847000]

Mitchell D, Archer GE, Bigner DD, Friedman HS, Lally-Goss D, J. E, Herndon I, McGehee S, McLendon R, Reardon DA, Sampson JH. Efficacy of a phase II vaccine targeting Cytomegalovirus antigens in newly diagnosed GBM. J Clin Oncol. 2008a; 26(May 20 suppl) abstr 2042.

Mitchell DA, Xie W, Schmittling R, Learn C, Friedman A, McLendon RE, Sampson JH. Sensitive detection of human cytomegalovirus in tumors and peripheral blood of patients diagnosed with glioblastoma. Neuro Oncol. 2008b; 10(1):10-8. [PubMed: 17951512]

Muhlestein JB, Horne BD, Carlquist JF, Madsen TE, Bair TL, Pearson RR, Anderson JL. Cytomegalovirus seropositivity and C-reactive protein have independent and combined predictive value for mortality in patients with angiographically demonstrated coronary artery disease. Circulation. 2000; 102(16):1917-23. [PubMed: 11034939]

Noda S, Aguirre SA, Bitmansour A, Brown JM, Sparer TE, Huang J, Mocarski ES. Cytomegalovirus MCK-2 controls mobilization and recruitment of myeloid progenitor cells to facilitate dissemination. Blood. 2006; 107(1):30-8. [PubMed: 16046529]

Orloff SL, Streblow DN, Soderberg-Naucler C, Yin Q, Kreklywich C, Corless CL, Smith PA, Loomis CB, Mills LK, Cook JW, Bruggeman CA, Nelson JA, Wagner CR. Elimination of donor-specific alloreactivity prevents cytomegalovirus-accelerated chronic rejection in rat small bowel and heart transplants. Transplantation. 2002; 73(5):679-88. [PubMed: 11907411]

Orloff SL, Yin Q, Corless CL, Orloff MS, Rabkin JM, Wagner CR. Tolerance induced by bone marrow chimerism prevents transplant vascular sclerosis in a rat model of small bowel transplant chronic rejection. Transplantation. 2000; 69(7):1295-303. [PubMed: 10798744]

Pampou S, Gnedoy SN, Bystrevskaya VB, Smirnov VN, Chazov EI, Melnick JL, DeBakey ME. Cytomegalovirus genome and the immediate-early antigen in cells of different layers of human aorta. Virchows Arch. 2000; 436(6):539-52. [PubMed: 10917167]

Penfold ME, Dairaghi DJ, Duke GM, Saederup N, Mocarski ES, Kemble GW, Schall TJ. Cytomegalovirus encodes a potent alpha chemokine. Proc Natl Acad Sci U S A. 1999; 96(17): 9839-44. [PubMed: 10449781]

Pulliam L. Cytomegalovirus preferentially infects a monocyte derived macrophage/microglial cell in human brain cultures: neuropathology differs between strains. J Neuropathol Exp Neurol. 1991; 50(4):432-40. [PubMed: 1648122]

Qavi HB, Melnick JL, Adam E, Debakey ME. Frequency of coexistence of cytomegalovirus and Chlamydia pneumoniae in atherosclerotic plaques. Cent Eur J Public Health. 2000; 8(2):71-3. [PubMed: 10857040] 
Randolph-Habecker JR, Rahill B, Torok-Storb B, Vieira J, Kolattukudy PE, Rovin BH, Sedmak DD. The expression of the cytomegalovirus chemokine receptor homolog US28 sequesters biologically active CC chemokines and alters IL-8 production. Cytokine. 2002; 19(1):37-46. [PubMed: 12200112]

Reinhardt B, Mertens T, Mayr-Beyrle U, Frank H, Luske A, Schierling K, Waltenberger J. HCMV infection of human vascular smooth muscle cells leads to enhanced expression of functionally intact PDGF beta-receptor. Cardiovasc Res. 2005; 67(1):151-60. [PubMed: 15949479]

Reinhardt B, Winkler M, Schaarschmidt P, Pretsch R, Zhou S, Vaida B, Schmid-Kotsas A, Michel D, Walther P, Bachem M, Mertens T. Human cytomegalovirus-induced reduction of extracellular matrix proteins in vascular smooth muscle cell cultures: a pathomechanism in vasculopathies? J Gen Virol. 2006; 87(Pt 10):2849-58. [PubMed: 16963742]

Reyes M, Dudek A, Jahagirdar B, Koodie L, Marker PH, Verfaillie CM. Origin of endothelial progenitors in human postnatal bone marrow. J Clin Invest. 2002; 109(3):337-46. [PubMed: 11827993]

Rice GP, Schrier RD, Oldstone MB. Cytomegalovirus infects human lymphocytes and monocytes: virus expression is restricted to immediate-early gene products. Proc Natl Acad Sci U S A. 1984; 81(19):6134-8. [PubMed: 6091137]

Ruoslahti E, Rajotte D. An address system in the vasculature of normal tissues and tumors. Annu Rev Immunol. 2000; 18:813-27. [PubMed: 10837076]

Schaarschmidt P, Reinhardt B, Michel D, Vaida B, Mayr K, Luske A, Baur R, Gschwend J, Kleinschmidt K, Kountidis M, Wenderoth U, Voisard R, Mertens T. Altered expression of extracellular matrix in human-cytomegalovirus-infected cells and a human artery organ culture model to study its biological relevance. Intervirology. 1999; 42(-):357-64. [PubMed: 10702718]

Scheurer ME, Bondy ML, Aldape KD, Albrecht T, El-Zein R. Detection of human cytomegalovirus in different histological types of gliomas. Acta Neuropathol. 2008; 116(1):79-86. [PubMed: 18351367]

Shen YH, Zhang L, Utama B, Wang J, Gan Y, Wang X, Chen L, Vercellotti GM, Coselli JS, Mehta JL, Wang XL. Human cytomegalovirus inhibits Akt-mediated eNOS activation through upregulating PTEN (phosphatase and tensin homolog deleted on chromosome 10). Cardiovasc Res. 2006; 69(2):502-11. [PubMed: 16316638]

Sindre H, Haraldsen G, Beck S, Hestdal K, Kvale D, Brandtzaeg P, Degre M, Rollag H. Human intestinal endothelium shows high susceptibility to cytomegalovirus and altered expression of adhesion molecules after infection. Scand J Immunol. 2000; 51(4):354-60. [PubMed: 10736107]

Sinzger C, Plachter B, Grefte A, The TH, Jahn G. Tissue macrophages are infected by human cytomegalovirus in vivo. J Infect Dis. 1996; 173(1):240-5. [PubMed: 8537667]

Soderberg-Naucler C. Does cytomegalovirus play a causative role in the development of various inflammatory diseases and cancer? J Intern Med. 2006; 259(3):219-46. [PubMed: 16476101]

Sparer TE, Gosling J, Schall TJ, Mocarski ES. Expression of human CXCR2 in murine neutrophils as a model for assessing cytomegalovirus chemokine vCXCL-1 function in vivo. J Interferon Cytokine Res. 2004; 24(10):611-20. [PubMed: 15626158]

Speir E, Huang ES, Modali R, Leon MB, Shawl F, Finkel T, Epstein SE. Interaction of human cytomegalovirus with p53: possible role in coronary restenosis. Scand J Infect Dis Suppl. 1995; 99:78-81. [PubMed: 8668947]

Speir E, Modali R, Huang ES, Leon MB, Shawl F, Finkel T, Epstein SE. Potential Role of Human Cytomegalovirus and p53 Interaction in Coronary Restenosis. Science. 1994; 265:391-4. [PubMed: 8023160]

Steinhoff G, You XM, Steinmuller C, Boeke K, Stals FS, Bruggeman CA, Haverich A. Induction of endothelial adhesion molecules by rat cytomegalovirus in allogeneic lung transplantation in the rat. Scand J Infect Dis Suppl. 1995; 99:58-60. [PubMed: 8668943]

Stetler-Stevenson WG. Matrix metalloproteinases in angiogenesis: a moving target for therapeutic intervention. J Clin Invest. 1999; 103(9):1237-41. [PubMed: 10225966]

Streblow DN, Dumortier J, Moses AV, Orloff SL, Nelson JA. Mechanisms of cytomegalovirusaccelerated vascular disease: induction of paracrine factors that promote angiogenesis and wound healing. Curr Top Microbiol Immunol. 2008a; 325:397-415. [PubMed: 18637518] 
Streblow DN, Kreklywich C, Yin Q, De La Melena VT, Corless CL, Smith PA, Brakebill C, Cook JW, Vink C, Bruggeman CA, Nelson JA, Orloff SL. Cytomegalovirus-mediated upregulation of chemokine expression correlates with the acceleration of chronic rejection in rat heart transplants. J Virol. 2003; 77(3):2182-94. [PubMed: 12525653]

Streblow DN, Kreklywich CN, Andoh T, Moses AV, Dumortier J, Smith PP, Defilippis V, Fruh K, Nelson JA, Orloff SL. The role of angiogenic and wound repair factors during CMV-accelerated transplant vascular sclerosis in rat cardiac transplants. Am J Transplant. 2008b; 8(2):277-87. [PubMed: 18093265]

Streblow DN, Orloff SL, Nelson JA. Do pathogens accelerate atherosclerosis? J Nutr. 2001; 131(10): 2798S-2804S. [PubMed: 11584110]

Streblow DN, Söderberg-Nauclér C, Vieira J, Smith P, Wakabayashi E, Rutchi F, Mattison K, Altschuler Y, Nelson JA. The human cytomegalovirus chemokine receptor US28 mediates vascular smooth muscle cell migration. Cell. 1999; 99:511-20. [PubMed: 10589679]

Tikkanen J, Kallio E, Pulkkinen V, Bruggeman C, Koskinen P, Lemstrom K. Cytomegalovirus infection-enhanced chronic rejection in the rat is prevented by antiviral prophylaxis. Transplant Proc. 2001; 33(1-2):1801. [PubMed: 11267518]

Valantine HA, Gao SZ, Santosh G. Impact of prophylactic immediate post-transplant ganciclovir on development of transplant atherosclerosis. A post-hoc analysis of a randomized, placebocontrolled study. Circulation. 1999; 100:61-66. al., e. [PubMed: 10393682]

Valente P, Fassina G, Melchiori A, Masiello L, Cilli M, Vacca A, Onisto M, Santi L, Stetler-Stevenson WG, Albini A. TIMP-2 over-expression reduces invasion and angiogenesis and protects B16F10 melanoma cells from apoptosis. Int J Cancer. 1998; 75(2):246-53. [PubMed: 9462715]

Vliegen I, Duijvestijn A, Grauls G, Herngreen S, Bruggeman C, Stassen F. Cytomegalovirus infection aggravates atherogenesis in apoE knockout mice by both local and systemic immune activation. Microbes Infect. 2004a; 6(1):17-24. [PubMed: 14738889]

Vliegen I, Duijvestijn A, Stassen F, Bruggeman C. Murine cytomegalovirus infection directs macrophage differentiation into a pro-inflammatory immune phenotype: implications for atherogenesis. Microbes Infect. 2004b; 6(12):1056-62. [PubMed: 15380774]

Vliegen I, Stassen F, Grauls G, Blok R, Bruggeman C. MCMV infection increases early T-lymphocyte influx in atherosclerotic lesions in apoE knockout mice. J Clin Virol. 2002; 25(Suppl 2):S159-71. [PubMed: 12361766]

Vomaske J, Melnychuk RM, Smith PP, Powell J, Hall L, DeFilippis V, Fruh K, Smit M, Schlaepfer DD, Nelson JA, Streblow DN. Differential ligand binding to a human cytomegalovirus chemokine receptor determines cell type-specific motility. PLoS Pathog. 2009; 5(2):e1000304. [PubMed: 19229316]

Wu TC, Hruban RH, Ambinder RF, Pizzorno M, Cameron DE, Baumgartner WA, Reitz BA, Hayward GS, Hutchins GM. Demonstration of cytomegalovirus nucleic acids in the coronary arteries of transplanted hearts. Am J Pathol. 1992; 140(3):739-47. [PubMed: 1312309]

Yamashiroya HM, Ghosh L, Yang R, Robertson AL. Herpesviredae in the coronary arteries and aorta of young trauma victims. Am. J. Path. 1988; 130:71-79. [PubMed: 2827495]

Zeng H, Waldman WJ, Yin DP, Knight DA, Shen J, Ma L, Meister GT, Chong AS, Williams JW. Mechanistic study of malononitrileamide FK778 in cardiac transplantation and CMV infection in rats. Transplantation. 2005; 79(1):17-22. [PubMed: 15714164]

Zhou YF, Leon MB, Waclawiw MA, Popma JJ, Yu ZX, Finkel T, Epstein SE. Association between prior cytomegalovirus infection and the risk of restenosis after coronary atherectomy. $\mathrm{N}$ Engl $\mathrm{J}$ Med. 1996; 335(9):624-30. [PubMed: 8687516]

Zhou YF, Shou M, Guzman R, Guetta E, Finkel T, Epstein SE. Cytomegalovirus infection increases neointimal fromation in the rat model of balloon injury. J Am Coll Cardiol. 1995; 25:242a. 


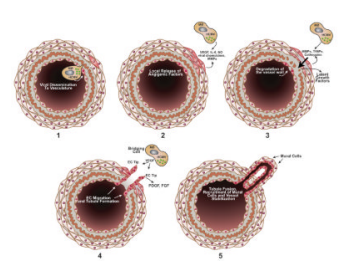

Figure 1. Role of HCMV in Angiogenesis

Depicted are the stages of angiogenesis and the role of HCMV in this process: 1) HCMV infected monocyte/macrophages disseminate virus to EC and SMC of the vasculature. 2) Infected cells release angiogenic growth factors (VEGF, IL-6, Nitric Oxide, etc.) and matrix metalloproteinases (MMPs). 3) Infected cells and locally activated cells release additional extracellular remodeling enzymes (MMPs, cathepsins, TIMPs, etc.) that degrade the vessel wall. 4) Growth factors released during vessel wall degradation promote EC migration towards the angiogenic stimulus and mediate EC proliferation, which drives the formation of the neotubules. Specialized macrophages promote the bridging of EC-tip cells fusing neighboring tubules into a complete circuit. 5) The newly formed tubules release growth factors (PDGF and FGF) that recruit Mural cells to stabilize the neovessel. 
Table 1

HCMV-Induced Angiogenic Factors

\begin{tabular}{|c|c|c|}
\hline Category & Angiogenic Factor & Reference \\
\hline Growth Factors & $\begin{array}{l}\text { Angiopoietin } \\
\text { Angiotensinogen } \\
\text { Fibroblast Growth Factor } \\
\text { Glial Derived Growth Factor } \\
\text { Granulocyte/Macrophage Colony Stimulating Factor } \\
\text { Hepatocyte Growth Factor } \\
\text { Insulin Growth Factor-Binding Protein } \\
\text { Osteopontin } \\
\text { Platelet Derived Growth Factor } \\
\text { PIGF } \\
\text { Transforming Growth Factor } \beta \\
\text { Vascular Endothelial Growth Factor }\end{array}$ & $\begin{array}{l}\text { Dumortier, } 2004 \\
\text { Inkinen, } 2003 \\
\text { Noda, } 2006 \\
\text { Streblow, 2008a } \\
\text { Streblow, 2008b }\end{array}$ \\
\hline Cytokines/Chemokines & $\begin{array}{l}\text { Interleukin } 6 \\
\text { Osteoprotegerin } \\
\text { CCL3-MIP1 } \alpha \\
\text { CCL5-RANTES } \\
\text { CCL7 } \\
\text { CCL20 } \\
\text { CXCL5-ENA78 } \\
\text { CXCL8-IL8 } \\
\text { CXCL10-IP10 } \\
\text { CXCL11-ITAC } \\
\text { CXCL16 } \\
\text { CX3CL1-Fractalkine }\end{array}$ & $\begin{array}{l}\text { Caposio, } 2007 \\
\text { Cheeran, } 2001 \\
\text { Dumortier, } 2004 \\
\text { Penfold, 1999 } \\
\text { Streblow, 2008a } \\
\text { Streblow, 2003 } \\
\text { Streblow, 2008b }\end{array}$ \\
\hline Viral Chemokines & $\begin{array}{l}\text { UL128 } \\
\text { UL146/vCXCL1 } \\
\text { UL147/vCXCL2 }\end{array}$ & $\begin{array}{l}\text { Beisser, } 2008 \\
\text { Penfold, } 1999 \\
\text { Sparer, } 2004\end{array}$ \\
\hline $\begin{array}{l}\text { Extracellular Matrix/ } \\
\text { Remodeling Enzymes }\end{array}$ & $\begin{array}{l}\text { Cathepsins } \\
\text { Collagen } \\
\text { Fibronectin } \\
\text { Laminin } \\
\text { Matrix Metalloproteinases } \\
\text { Tissue Inhibitors of MMPs } \\
\text { Thrombospondin } \\
\text { uPAR }\end{array}$ & $\begin{array}{l}\text { Dumortier, } 2004 \\
\text { Schaarschmidt, } 1999 \\
\text { Streblow, 2008a } \\
\text { Streblow, 2008b }\end{array}$ \\
\hline Adhesion Molecules & $\begin{array}{l}\text { ICAM-1 } \\
\text { PECAM-1 } \\
\text { VCAM-1 } \\
\text { VE-cadherin }\end{array}$ & $\begin{array}{l}\text { Caposio, } 2007 \\
\text { Dengler, } 2000 \\
\text { Dumortier } 2004 \\
\text { Streblow, 2008a } \\
\text { Streblow, 2008b }\end{array}$ \\
\hline
\end{tabular}

